\title{
Study on Differences in Correlation between the Accounting Data and Stock Price of China and Thailand based on Ohlson Model
}

\author{
Yongling Zhang \\ Panyapiwat Institute of Management \\ Bangkok, Thailand \\ Guihua Lu \\ Panyapiwat Institute of Management, \\ Bangkok, Thailand \\ Central University of Finance and Economics,
}

\author{
Beijing, China
}

Wenyun Zhou*

1. Panyapiwat Institute of Management

2. International Business School of YUFE

International Business School

Yunnan University of Finance and economics

Kunming, China

wyzhou2005@163.com

\begin{abstract}
This paper compares the correlation between the accounting data and the stock price of China and Thailand by using the Ohlson residual income valuation model base on the 10680 companies' data of 1068 listed companies during 2007 to 2016. The total assets of the company, the number of circulating shares and the time of listing are regarded as the control variables. It is found that the earnings per share and the book value per share of the listed companies in both countries have different meanings to the stock price. The explanatory power of the earnings per share and the book value per share of the listed companies in Thailand is stronger than those of the listed companies in China. And the longer the company goes on the market, the higher the explanatory power of the accounting data to the stock price. And Thailand listed companies are generally better than listed companies in China. On the other hand, the Thai investors pay more attention to the analysis of the fundamentals of listed companies.
\end{abstract}

Keywords-Ohlson mode; accounting information; EPS; BVPS stock price

\section{INTRODUCTION}

The emergence of stock market has promoted economic and social development, and liberated and developed social productive forces, which is an important milestone in the process of human economic and social modernization. It is an important distribution center of economic and social information and capital, has independent resource allocation mechanism and regulation control mechanism.

In August 2016, President $\mathrm{Xi}$ Jinping, in the work symposium for advancing the Belt and Road Initiative construction, pointed out that we should promote financial innovation, deepen cooperation in financial field, establish international financing mode, build multi-level financial platform, and establish a long-term, stable and risk-controllable financial security system for the construction of "One Belt and One Road". The securities exchange market is an important financial organ of the country, whose responsibility relates to the people's livelihood, trade, government, and economy

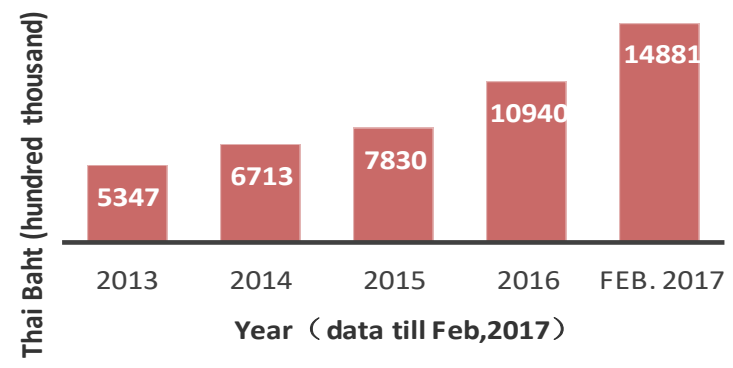

Data source: Stock Exchange of Thailand (SET)

Fig. 1. Daily average trading volume of foreign investors in Thailand

and so on. Stock market is also an important place for securities trading. Besides, the stock market has great influence on the economic growth and the integration of the world economy.

Nowadays, with the development of financial globalization, it has strengthened the international capital flows around China and the whole Asia-Pacific region. Since the stock market is the most important part of capital market, its capital fluidity is gradually strengthened. With the improvement of investment environment of international capital market and the gradual loosening of capital control, along with the implementation of "the Belt and Road Initiative", many investors are looking to expand overseas. Thailand, one of the world's largest Chinese destinations and a gateway to 600 million of Southeast Asian consumers, has become one of the leading consumers of Chinese investment.

With the faster pace of international financial integration, more and more Chinese investors choose to buy and sell stocks in Thailand. Figure 1 is the daily average trading volume of

*Corresponding author 
foreign investors buying and selling shares in Thailand. From 2013 to 2017 February, the daily average trading volume is increasing. This paper will use the Ohlson residual income valuation model to analyze whether the accounting information of the listed companies of China and Thailand has different explanatory power to the stock price, and whether the empirical data of Chinese stock market can be used in the Thai stock market. It will provide a reference for the investment of Chinese investors in the Thai stock market.

\section{BASIC DISCUSSION ON THE OHLSON RESIDUAL INCOME VALUATION MODEL}

Based on the research of Edward \& Bell and Peasnell, Ohlson [7] put forward the model of residual income valuation And Ohlson systematically studied the residual income model from 1982 to 1995 . He proposed a model of residual income valuation that could be directly used in accounting data, and published a far-reaching paper, Earnings, Book Values, and Dividends in Equity Valuation. This marks the residual income model stepped from the classical to the modern, but also the beginning of the residual income model from the theory to practice. Since then, the Ohlson residual income valuation model has become one of the most popular research topics in the global finance field. Meanwhile, the Ohlson valuation model has been rapidly adopted by American consulting firms, investment banks and evaluation companies, and has gradually received worldwide attention.

The classical residual income model refers to the model proposed by Edwards \& Bell, Peasnell and Ohlson before 1995, which is called the EBO model in academia. And its specific expression is as follows:

$$
V_{t}=B V_{o}+\sum \frac{R I_{t}}{(1+r)^{t}}
$$

Wherein, represents the equity value of the enterprise in the time of $\mathrm{T}$, and is the book value of the interest as well as the book value of the net assets. And is the residual income of the enterprise in the time of $\mathrm{T}$, while is the equity capital cost rate.

The Ohlson [7] valuation model is the mostly commonly used model in the modern residual income valuation model, and the assumption of residual income and other information variables follows the first order autoregressive process, which solves the problem of unpredictable residual income in the EBO model. And the expression is as follows:

$$
x_{t+1}^{a}=\omega_{1} x_{t}^{a}+\omega_{2} v_{t}+\varepsilon_{t+1}
$$

The value of an enterprise (or stock) can be expressed as:

$$
V_{t}=b v_{t}+\alpha_{1} x_{t}^{a}+\alpha_{2} v_{t}
$$

In which, $\omega_{1}$ and $\omega_{2}$ are the coefficients of the remaining income variable and other information variables, which should be between $[0,1]$.

$$
a_{l}=\frac{\omega_{1}}{1+r-\omega_{1}} \geq 0
$$

$$
a_{2}=\frac{1+r}{\left(1+r-\omega_{1}\right)\left(1+r-\omega_{2}\right)}>0
$$

If the non-accounting information variable $v$ is treated as a constant, the formula becomes as follows:

$$
x_{t+1}^{a}=\omega_{0}+\omega_{1} x_{t}^{a}+\varepsilon_{t+1}
$$

The value form of the enterprise is changed to:

$V_{t}=b v_{t}+\alpha_{1} x_{t}^{a}+\alpha_{0}$

In which, $a_{0}=\frac{(1+r) \omega_{0}}{\left(1+r-\omega_{1}\right)\left(1+r-\omega_{0}\right)}$

$$
a_{l}=\frac{\omega_{l}}{1+r-\omega_{l}}
$$

Feltham-Ohlson [7] residual income valuation model takes into account that the residual income is not only related to other non-accounting information variables $v$, but also to the net assets of the company. Therefore, the model breaks down the net assets into two parts of financial assets and operating assets. But it is difficult to distinguish these two kinds of assets in practice, so it is not distinguished in the general expression. The formula is expressed as follows:

$$
x_{t+1}^{a}=\omega_{1} x_{t}^{a}+\omega_{2} b v_{t}+\omega_{3} v_{t}+\varepsilon_{t+1}
$$

The value of an enterprise (or stock) is expressed as:

$V_{t}=b v_{t}+\alpha_{1} x_{t}^{a}+\alpha_{2} b v_{t}+\alpha_{3} v_{t}$

Wherein,

$$
\begin{aligned}
& a_{1}=\frac{\omega_{1}}{1+r-\omega_{1}} \\
& a_{2}=\frac{(1+r) \omega_{2}}{r\left(1+r-\omega_{1}\right)} \\
& a_{3}=\frac{1+r}{\left(1+r-\omega_{1}\right)\left(1+r-\omega_{3}\right)}
\end{aligned}
$$

\section{EMPIRICAL ANALYSIS OF THE DIFFERENCE BETWEEN THE ACCOUNTING DATA OF CHINA AND THAILAND LISTED COMPANIES ON STOCK PRICING}

\section{A. The Definition of Variables}

This paper uses Osiris global listed company database to obtain stock data from 2007 to 2016 in China and Thailand. Except financial listed companies, companies with negative price/book value ratio or incomplete data companies, there are a total of 10,680 data of 1068 listed companies for 10 years, in which it includes 2,470 company data of Thailand and 8,210 company data of China.

As an interpreted variable, the letter $\mathrm{P}$ represents the stock price, and Dum is a dummy variable. The Chinese company is set as 1 , and the Thai company set as 0 . Explanatory variable EPS is earnings per share; BVPS is book value per-share; the control variable SIZE indicates the size of the listed company, taking the logarithm of the total assets of the company. The 
total assets of the number i company at the end of t year is , . indicates the listed years of the number i company at the end of $t$ year. The natural logarithm of the number of days to be listed by the date of listing to the end of the $t$ year should be expressed as, and the is the number of tradable shares of the number $\mathrm{i}$ company at the end of $\mathrm{t}$ year. And is its natural logarithm.

According to the Olhson residual income valuation model, is defined as the stock prices of the number i Chinese listed company at the end of $t$ year. is the stock price for the $\mathrm{j}$ Thai listed company at the end of the year of t. represents the earnings per share of the number i Chinese listed company at the end of $t$ year. And represents the earnings per share of the number $\mathrm{j}$ Thai listed company at the end of the year of $t$. is the book value per share of the number $\mathrm{i}$ Chinese listed company at the end of $t$ year, while indicates the book value per share of the number $\mathrm{j}$ Thai listed company at the end of the year of $\mathrm{t}$.

$$
\begin{aligned}
& P_{i t}=\alpha_{0}+\alpha_{1} \times \operatorname{Dum}_{i t}+\alpha_{2} \times E P S_{i t}+\alpha_{3} \times \operatorname{Dum}_{i t} \times E P S_{i t}+ \\
& \alpha_{4} \times B V P S_{i t}+\alpha_{5} \times D_{i t} \times B V P S_{i t}+b_{1} \times S I Z E_{i t}+ \\
& b_{2} \times T I M E_{i t}+b_{3} \ln T S_{i t}+\varepsilon_{i t}
\end{aligned}
$$$$
P_{i t}^{C}=\alpha_{0}+\alpha_{1}^{C} E P S_{i t}^{C}+\alpha_{2}^{C} B V P S_{i t}^{C}+\varepsilon_{i t}^{C}
$$$$
P_{j t}^{T}=\alpha_{0}+\alpha_{1}^{T} E P S_{j t}^{T}+\alpha_{2}^{T} B V P S_{j t}^{T}+\varepsilon_{j t}^{T}
$$$$
P_{i t}^{C}=\alpha_{0}+\alpha_{1}^{C} E P S_{i t}^{C}+\alpha_{2}^{C} B V P S_{i t}^{C}+\alpha_{3}^{C} T I M E_{i t}^{C}+\varepsilon_{i t}^{C}
$$$$
P_{j t}^{T}=\alpha_{0}+\alpha_{1}^{T} E P S_{j t}^{T}+\alpha_{2}^{T} B V P S_{j t}^{T}+\alpha_{3}^{T} T I M E_{j t}^{T}+\varepsilon_{j t}^{T}
$$

The model (1) is used to test the difference between the accounting data of the listed companies of China and Thailand on the meaning of the stock price. If $\alpha 1$ is significant, it indicates that there are significant differences in the price of stock in these two countries. If $\alpha 3$ is significant, it shows that there is a significant difference in the reaction coefficient between the stock price and the earnings per share in two countries. If $\alpha 5$ is significant, it means that the stock price of the two countries has significant difference in the reaction coefficient of earnings per share. Model (2) and model (3) are used to compare the correlation and explanatory power of the accounting data between the two countries. The model (4) and model (5) respectively indicate that the time of company listing affects the incremental explanatory power of accounting data to the explanatory power of stock price.

$$
R_{0}^{c} \text { is set as the goodness of fit in model (2), and } R_{1}^{\mathrm{c}} \text { is the }
$$
goodness of fit in model (4). $R^{c}=R_{1}^{c}-R_{0}^{c}$ means the incremental explanatory force of the length of listed time of Chinese companies to the stock price. ${ }^{R_{0}^{T}}$ is the goodness of fit in model (3), and $R_{1}^{T}$ is the goodness of fit in model (5). $R^{T}=R_{1}^{T}-R_{0}^{T}$ the length of listed time of Thai companies to the stock price.

\section{A. Descriptive Statistics of Variables}

A descriptive statistical analysis of the 10-year data of Chinese listed companies and a descriptive statistical analysis of the 10-year data of the listed companies in Thailand are presented in TABLE I and TABLE II. It can be observed that the average stock price of Chinese listed companies is higher than that of Thai companies. And the median price of Chinese companies is slightly below average, while the median number of Thai companies is far below the mean value, which reflects the overall price of Chinese listed companies is higher than the Thai listed companies. The average earnings per share of Chinese companies is much lower than that of Thai companies, reflecting the fact that Chinese investors are not particularly concerned about the company's earnings, and that Chinese companies' share prices are overvalued compared with Thai companies. The assets of listed companies in China are generally higher than those of the listed companies in Thailand, and the number of circulation shares in the listed companies in Thailand is lower than that of Chinese companies.

\section{B. Correlation Analysis of Variables}

TABLE III conducts the correlation analysis of the univariate in model (1). From it, we can see the following characteristics. First, the virtual variable Dum and Price $(\mathrm{P})$, EPS, and BVPS are significantly correlated. Price shows a significant correlation with the EPS, BVPS, TIME, the logarithm of the total assets of the company and the logarithm of the circulating stocks.

\section{Empirical Findings}

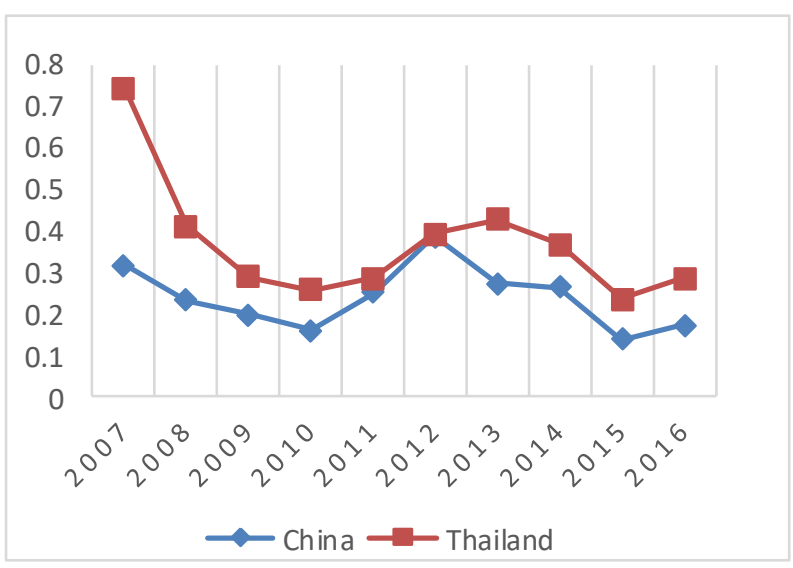

Fig. 2. The explanatory power of the accounting data of China and Thailand to the stock price in the year

The empirical test result of TABLE IV is the regression of total sample of model (1). It can be found that the virtual variable Dum is significantly correlated with the stock price $(\mathrm{P})$ at $1 \%$ level, which indicates that there are significant differences in the stock pricing of the listed companies in China and Thailand. The virtual variable multiplied by the earnings per share, DUM*EPS, is significantly correlated with the stock price $(\mathrm{P})$ at $1 \%$ level, which shows that there is a significant difference in the reaction coefficient between the stock prices of China and Thailand. The virtual variable 
multiplied by the book value per share, DUM*BVPS, is significantly correlated with the stock price $(\mathrm{P})$ at $1 \%$ level, which indicates there is a significant difference in the reaction coefficient between the stock price of the listed companies in China and Thailand for the book value of each share. The EPS and the BVPS of the listed companies in Thailand are positively correlated with the stock price. The EPS of Chinese accounting data of the two countries' listed companies. From it, it can be seen in the background of the global financial crisis in 2008, the explanatory power of the accounting data for the stock prices has a significant downward trend. The analysis results show that the explanatory power of the company's accounting data for the stock price is generally better than that of the Chinese listed companies.

From TABLE VI to TABLE IX, it's the regression analysis of the model (2) to model (4), in which,

$$
\begin{aligned}
& R^{C}=R_{1}^{C}-R_{0}^{C}=0.2029-0.1920=0.0109 \\
& R^{T}=R_{1}^{T}-R_{0}^{T}=0.2652-0.2280=0.0372
\end{aligned}
$$

The incremental explanatory power of the market time for the stock price is $3.72 \%$. The length of the listing time of the listed companies in Thailand is significantly higher than that of the Chinese companies in explaining the stock price.

\section{SUMMARY}

Base on the Ohlson valuation model, this paper examines the difference between the earnings per share and the book value per share and the stock price of the listed companies in China and Thailand, by selecting the 10-year data of the listed companies in China and Thailand and taking the time of listing, the size of the total assets and the number of circulating stocks as the variables. The results show that the earnings per share and the book value per share of the listed companies in China and Thailand have different meanings to the stock price. The EPS and the book value per share (BVPS) of the listed companies in Thailand are positively correlated with the stock price. However, the EPS of the listed companies in China is positively correlated with the stock price, while the BVPS is negatively correlated with the book value and stock price of each share. Besides, the stock data of the listed companies in Thailand is more explanatory to the stock price than the Chinese listed companies. listed companies are positively correlated with the stock price, but the BVPS is negatively correlated with the stock price.

TABLE $\mathrm{V}$ is the goodness of fit based on the analysis of the correlation between the accounting data and the stock price of the listed companies in China and Thailand in the year. In Fig. 2, it is the regression analysis of the value correlation of

As the company goes on the market for a longer time, the accounting data is more explanatory to the stock price, and the likelihood of accounting data fraud is lower. Similarly, the time of the listing of Thai listed companies is higher than that of Chinese listed companies in the incremental interpretation of stock prices; on the other hand, Thai investors are more focused on the fundamentals of listed companies than Chinese investors

\section{REFERENCE}

[1] M.J. Brennan, \& A. Subrahmanyam, "Cross-sectional determinants of expected returns," Pediatric Pulmonology, Vol. 24, pp. 391-396, November 1998.

[2] M.J. Brennan, T. Chordia, \& A. Subrahmanyam, "Alternative factor specifications, security characteA. ristics, and the cross-section of expected stock returns", Journal of Financial Economics, Vol.49, 1998, pp. 345-373.

[3] D.W. Collins, E.L. Maydew, \& I.S. Weiss, "Changes in the valuerelevance of earnings and book values over the past forty years", Journal of Accounting \& Economics, Vol. 24, 1997, pp. 39-67.

[4] M. Delkhosh, "Correlation between accounting information and stock price", International Journal of Multidisciplinary Research and Development, Vol. 3, pp. 294-2977, February, 2016.

[5] Y. Ding, O.K. Hope, J. T. eanjean, \& H. Stolowy, "Differences between domestic accounting standards and IAS: measurement, determinants and implications", Journal of Accounting \& Public Policy, Vol.26(1), pp. 138, January-February, 2007.

[6] J. Francis, P. Olsson, \& D.R. Oswald, "Comparing the accuracy and explainability of dividend, free cash flow and abnormal earnings equity valuation models", Journal of Accounting Research, Vol. 38, 2012, pp. 45-70.

[7] J.A. Ohlson, "Earnings, book values, and dividends in equity valuation", Contemporary Accounting Research, Vol. 11, 1995, pp. 661-687.

[8] J.A. Ohlson, \& B.E. uettner-Nauroth, "Expected eps and eps growth as determinants of value", Review of Accounting Studies, Vol. 10, 2005, pp 349-365.

[9] J.W. Wang, \& W.W. Yu, "The information content of stock prices,legal environments, and accounting standards: international evidence", European Accounting Review, Vol. 24, 2015, pp. 1-23. 
SCHEDULE

TABLE I. DESCRIPTIVE STATISTICAL RESULt OF VARIABLE INDICATORS FOR LiSTED COMPANIES IN CHINA

\begin{tabular}{|c|c|c|c|c|c|c|}
\hline & P & EPS & BVPS & TIME & SIZE & LNTS \\
\hline Mean & 1.532393 & 0.062159 & 0.819206 & 8.455353 & 13.28254 & 13.01989 \\
\hline Median & 1.178464 & 0.028499 & 0.538797 & 8.540128 & 13.18200 & 12.95883 \\
\hline Maximum & 48.08052 & 3.110781 & 23.37938 & 9.309733 & 18.59920 & 16.90832 \\
\hline Minimum & 0.058061 & -1.268434 & 0.001695 & 5.905362 & 9.627200 & 9.911517 \\
\hline Std. Dev. & 1.589484 & 0.160249 & 1.144341 & 0.423467 & 1.261879 & 0.942205 \\
\hline Skewness & 9.823474 & 6.251537 & 7.512447 & -1.615562 & 0.473309 & 0.506215 \\
\hline Kurtosis & 192.3307 & 76.69834 & 96.55004 & 7.585481 & 3.449629 & 4.082437 \\
\hline Jarque-Bera & 12394397 & 1911484. & 3071004. & 10764.27 & 375.6937 & 751.4494 \\
\hline Probability & 0.000000 & 0.000000 & 0.000000 & 0.000000 & 0.000000 & 0.000000 \\
\hline Sum & 12580.94 & 510.3237 & 6725.677 & 69418.44 & 109049.6 & 106893.3 \\
\hline Sum Sq. Dev. & 20739.71 & 210.8063 & 10749.82 & 1472.071 & 13071.52 & 7287.545 \\
\hline Observations & 8210 & 8210 & 8210 & 8210 & 8210 & 8210 \\
\hline
\end{tabular}

TABLE II. DESCRIPTIVE StATISTICAL RESUlt OF VARIABLE INDICATORS FOR Listed COMPANIES IN THAilAND

\begin{tabular}{|c|c|c|c|c|c|c|}
\hline & P & EPS & BVPS & TIME & SIZE & LNTS \\
\hline Mean & 1.050166 & 0.118484 & 1.032370 & 8.603629 & 11.82859 & 12.72874 \\
\hline Median & 0.220618 & 0.015090 & 0.161512 & 8.789279 & 11.51905 & 12.87888 \\
\hline Maximum & 97.68160 & 15.46858 & 77.67303 & 9.630169 & 18.03900 & 17.32311 \\
\hline Minimum & 0.003915 & -1.270440 & 0.001116 & 6.150603 & 8.596100 & 7.779615 \\
\hline Std. Dev. & 3.730743 & 0.694281 & 4.002391 & 0.615064 & 1.552911 & 1.730345 \\
\hline Skewness & 13.58534 & 14.24004 & 11.38164 & -1.030451 & 0.991403 & -0.308252 \\
\hline Kurtosis & 267.7301 & 242.9689 & 163.4774 & 3.771512 & 3.811673 & 3.042432 \\
\hline Jarque-Bera & 7288584. & 6009940. & 2703741. & 498.3791 & 472.4220 & 39.30163 \\
\hline Probability & 0.000000 & 0.000000 & 0.000000 & 0.000000 & 0.000000 & 0.000000 \\
\hline Sum & 2593.911 & 292.6554 & 2549.955 & 21250.96 & 29216.61 & 31440.00 \\
\hline Sum Sq. Dev. & 34364.64 & 1190.122 & 39551.25 & 934.0309 & 5954.072 & 7392.418 \\
\hline Observations & 2470 & 2470 & 2470 & 2470 & 2470 & 2470 \\
\hline
\end{tabular}

TABLE III. CORRELATION ANALYSIS OF VARIABLES

\begin{tabular}{|c|c|c|c|c|c|c|c|c|c|}
\hline \multicolumn{2}{|c|}{ Correlation } & \multirow[b]{2}{*}{$\mathrm{P}$} & \multirow[b]{2}{*}{ EPS } & \multirow[b]{2}{*}{ BVPS } & \multirow[b]{2}{*}{ TIME } & \multirow[b]{2}{*}{ SIZE } & \multirow[b]{2}{*}{ LNTS } & \multirow[b]{2}{*}{ DUM*EPS } & \multirow[b]{2}{*}{ DUM*BVPS } \\
\hline Probability & DUM & & & & & & & & \\
\hline \multirow[t]{2}{*}{ DUM } & 1.000000 & & & & & & & & \\
\hline & ----- & & & & & & & & \\
\hline \multirow[t]{2}{*}{$\mathrm{P}$} & 0.089252 & 1.000000 & & & & & & & \\
\hline & 0.0000 & \begin{tabular}{l|}
---- \\
-
\end{tabular} & & & & & & & \\
\hline \multirow[t]{2}{*}{ EPS } & -0.065459 & 0.382686 & 1.000000 & & & & & & \\
\hline & 0.0000 & 0.0000 & \begin{tabular}{|l|}
----- \\
\end{tabular} & & & & & & \\
\hline \multirow[t]{2}{*}{ BVPS } & -0.041439 & 0.369551 & 0.885648 & 1.000000 & & & & & \\
\hline & 0.0000 & 0.0000 & 0.0000 & \begin{tabular}{l|}
---- \\
-4
\end{tabular} & & & & & \\
\hline \multirow[t]{2}{*}{ TIME } & -0.130565 & 0.101757 & 0.091404 & 0.147694 & 1.000000 & & & & \\
\hline & 0.0000 & 0.0000 & 0.0000 & 0.0000 & \begin{tabular}{l|l|}
---- \\
-1
\end{tabular} & & & & \\
\hline \multirow[t]{2}{*}{ SIZE } & 0.417693 & 0.138772 & 0.148421 & 0.201669 & 0.098853 & 1.000000 & & & \\
\hline & 0.0000 & 0.0000 & 0.0000 & 0.0000 & 0.0000 & \begin{tabular}{|l|}
---- \\
-1
\end{tabular} & & & \\
\hline \multirow[t]{2}{*}{ LNTS } & 0.104386 & -0.157224 & -0.126348 & -0.218939 & -0.031141 & 0.623521 & 1.000000 & & \\
\hline & 0.0000 & 0.0000 & 0.0000 & 0.0000 & 0.0013 & 0.0000 & ----- & & \\
\hline \multirow{2}{*}{ DUM*EPS } & 0.183339 & 0.276768 & 0.368453 & 0.305968 & $-3.95 \mathrm{E}-05$ & 0.259170 & -0.039212 & 1.000000 & \\
\hline & 0.0000 & 0.0000 & 0.0000 & 0.0000 & \begin{tabular}{l|l|}
0.9967 \\
\end{tabular} & 0.0000 & 0.0001 & ----- & \\
\hline \multirow[t]{2}{*}{ DUM*BVPS } & 0.325751 & 0.175420 & 0.231588 & 0.422809 & 0.053733 & 0.388521 & -0.060116 & 0.702140 & 1.000000 \\
\hline & 0.0000 & 0.0000 & 0.0000 & 0.0000 & 0.0000 & 0.0000 & 0.0000 & 0.0000 & ----- \\
\hline
\end{tabular}


TABLE IV. CORRELATION ANALYSIS OF ACCOUNTING DATA AND STOCK PRICE OF CHINA AND THAILAND

\begin{tabular}{|c|c|c|c|c|}
\hline Prob(F-statistic) & 0.000000 & & & \\
\hline Variable & Coefficient & Std. Error & t-Statistic & Prob. \\
\hline $\mathrm{C}$ & 0.535358 & 0.419890 & 1.274996 & 0.2023 \\
\hline DUM & 0.386011 & 0.057333 & 6.732761 & 0.0000 \\
\hline EPS & 0.562076 & 0.166253 & 3.380847 & 0.0007 \\
\hline DUM*EPS & 4.493323 & 0.252666 & 17.78367 & 0.0000 \\
\hline BVPS & 0.214934 & 0.030159 & 7.126586 & 0.0000 \\
\hline DUM*BVPS & -0.57378 & 0.038993 & -14.71503 & 0.0000 \\
\hline TIME & 0.260460 & 0.042189 & 6.173692 & 0.0000 \\
\hline SIZE & 0.379527 & 0.023905 & 15.87679 & 0.0000 \\
\hline LNTS & -0.51096 & 0.026746 & -19.10409 & 0.0000 \\
\hline R-squared & 0.228355 & \multicolumn{2}{|c|}{ Mean dependent var } & $\begin{array}{r}1.42086 \\
6 \\
\end{array}$ \\
\hline $\begin{array}{c}\text { Adjusted R- } \\
\text { squared }\end{array}$ & 0.227777 & \multicolumn{2}{|c|}{ S.D. dependent var } & $\begin{array}{r}2.28066 \\
1 \\
\end{array}$ \\
\hline S.E. of regression & 2.004158 & \multicolumn{2}{|c|}{ Akaike info criterion } & $\begin{array}{r}4.22916 \\
8 \\
\end{array}$ \\
\hline Sum squared resid & 42861.68 & \multicolumn{2}{|c|}{ Schwarz criterion } & $\begin{array}{r}4.23529 \\
9 \\
\end{array}$ \\
\hline Log likelihood & -22574.8 & \multicolumn{2}{|c|}{ Hannan-Quinn criter. } & $\begin{array}{r}4.23123 \\
6 \\
\end{array}$ \\
\hline F-statistic & 394.7384 & \multicolumn{2}{|c|}{ Durbin-Watson stat } & $\begin{array}{r}0.31016 \\
0 \\
\end{array}$ \\
\hline
\end{tabular}

TABLE V. CHINA-THAILAND LISTED COMPANIES ACCOUNTING DATA FOR THE EXPLANATORY POWER OF STOCK PRICES IN GOODNESS OF FIT BY YEAR

\begin{tabular}{|c|c|c|}
\hline Year & $\begin{array}{c}\text { Chinese Company } \\
\left(R_{0}^{C}\right)\end{array}$ & Thai Company $\left(R_{0}^{T}\right)$ \\
\hline 2007 & 0.316657 & 0.743830 \\
\hline 2008 & 0.231420 & 0.413375 \\
\hline 2009 & 0.197396 & 0.290233 \\
\hline 2010 & 0.159680 & 0.258901 \\
\hline 2011 & 0.252581 & 0.287703 \\
\hline 2012 & 0.385767 & 0.392888 \\
\hline 2013 & 0.275070 & 0.427666 \\
\hline 2014 & 0.264156 & 0.366962 \\
\hline 2015 & 0.138191 & 0.23579 \\
\hline 2016 & 0.172376 & 0.284970 \\
\hline
\end{tabular}

TABLE VI. CORRELATION ANALYSIS BETWEEN EARNINGS PER SHARE AND BoOK VALUe PER SHARE AND STOCK PRICE OF CHINESE LISTED COMPANIES

\begin{tabular}{|l|l|l|l|l|}
\hline Variable & Coefficient & Std. Error & t-Statistic & Prob. \\
\hline C & 1.328538 & 0.019536 & 68.00617 & 0.0000 \\
\hline EPS & 4.908801 & 0.136182 & 36.04595 & 0.0000 \\
\hline BVPS & -0.123620 & 0.019070 & -6.482296 & 0.0000 \\
\hline R-squared & 0.202861 & Mean dependent var & 1.532393 \\
\hline Adjusted R-squared & 0.191764 & S.D. dependent var & 1.589484 \\
\hline S.E. of regression & 1.428977 & \multicolumn{2}{|l|}{ Akaike info criterion } & 3.552161 \\
\hline Sum squared resid & 16758.50 & \multicolumn{2}{|l|}{ Schwarz criterion } & 3.554723 \\
\hline Log likelihood & -14578.62 & \multicolumn{2}{|l|}{ Hannan-Quinn criter. } & 3.553037 \\
\hline F-statistic & 974.8418 & \multicolumn{2}{|c|}{ Durbin-Watson stat } & 0.536658 \\
\hline Prob(F-statistic) & 0.000000 & \multicolumn{2}{|l|}{} \\
\hline
\end{tabular}

TABLE VII. THE INCREMENTAL EXPLANATION OF THE TIME OF LISTING OF CHINESE LISTED COMPANIES IN THE STOCK PRICE

\begin{tabular}{|l|l|l|l|l|}
\hline Variable & Coefficient & Std. Error & t-Statistic & Prob. \\
\hline C & -0.955903 & 0.316666 & -3.018649 & 0.0025 \\
\hline EPS & 4.990244 & 0.136225 & 36.63224 & 0.0000 \\
\hline BVPS & -0.144663 & 0.019233 & -7.521688 & 0.0000 \\
\hline TIME & 0.271617 & 0.037580 & 7.227724 & 0.0000 \\
\hline R-squared & 0.217072 & Mean dependent var & 1.532393 \\
\hline Adjusted R-squared & 0.216779 & S.D. dependent var & 1.589484 \\
\hline S.E. of regression & 1.424537 & \multicolumn{2}{|l|}{ Akaike info criterion } & 3.546058 \\
\hline Sum squared resid & 16652.49 & \multicolumn{2}{|l|}{ Schwarz criterion } & 3.549475 \\
\hline Log likelihood & -14552.57 & \multicolumn{2}{|l|}{ HannanQuinn criter. } & 3.547226 \\
\hline F-statistic & 671.3655 & \multicolumn{2}{|c|}{ Durbin-Watson stat } & 0.542037 \\
\hline Prob(F-statistic) & 0.000000 & & & \\
\hline
\end{tabular}

TABLE VIII. CORRELATION ANALYSIS BETWEEN EARNINGS PER SHARE AND BoOK Value Per SHaRe AND STOCK PRICE OF Listed COMPANIES IN THAILAND

\begin{tabular}{|l|l|l|l|l|}
\hline Variable & Coefficient & Std. Error & t-Statistic & Prob. \\
\hline C & 0.617456 & 0.071086 & 8.686086 & 0.0000 \\
\hline EPS & -0.331548 & 0.268615 & -1.234288 & 0.0172 \\
\hline BVPS & 0.457195 & 0.046596 & 9.811940 & 0.0000 \\
\hline R-squared & 0.227983 & Mean dependent var & 1.050166 \\
\hline Adjusted R-squared & 0.227325 & S.D. dependent var & 3.730743 \\
\hline S.E. of regression & 3.363209 & Akaike info criterion & 5.264882 \\
\hline Sum squared resid & 27904.67 & Schwarz criterion & 5.271941 \\
\hline Log likelihood & -6499.130 & Hannan-Quinn criter. & 5.267447 \\
\hline F-statistic & 285.5566 & Durbin-Watson stat & 0.152443 \\
\hline Prob(F-statistic) & 0.000000 & \multicolumn{2}{|l|}{} & \\
\hline
\end{tabular}

